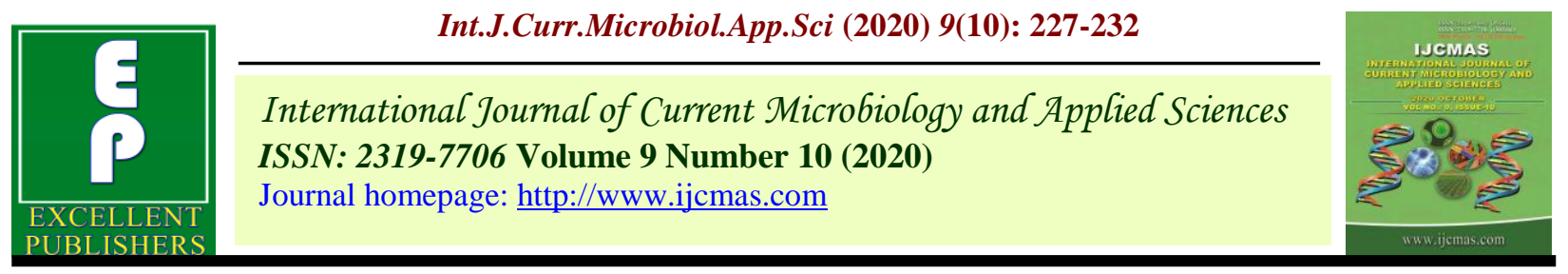

Original Research Article

https://doi.org/10.20546/ijcmas.2020.910.029

\title{
Study of Soil Organic Carbon and Microbial Population Dynamics under different Bamboo Species in Mollisols of Terai Region of Uttrakhand, India
}

\author{
N. Sharma*, G.K. Dwivedi and N.S. Danu
}

Department of Agrforestry, College of Agriculture, G.B. Pant University of Agriculture and Technology, Pantnagar, District Udham Singh Nagar, Uttrakhand, India

*Corresponding author

\section{A B S T R A C T}

Keywords

Bamboos, Bacteria, Fungus,

Actinomycetes,

Soil organic carbon (SOC) stock

Article Info

Accepted:

04 September 2020

Available Online:

10 October 2020
The present study was undertaken at the experimental site situated at Agroforestry Research Centre, Haldi of G.B. Pant University of Agriculture and Technology, Pantnagar, Uttarakhand. Bamboo as species has many economical and ecological benefits. Soil samples collected under six different bamboo species namely Dendrocalamus hamiltonii, Bambusa nutans, Dendrocalamus asper Bambusa bambos Bambusa balcooa and Dendrocalamus strictus showed significant increase in microbial population and soil organic carbon (SOC) than open plot (control). Maximum bacterial $\left(67.87 \times 10^{6} \mathrm{cfu} \mathrm{g}^{-1}\right)$ and actinomycetes $\left(53.17 \times 10^{5}\right.$ $\mathrm{cfu}^{-1}$ ) population was showed under D. hamiltonii. Microbial populations and soil organic carbon (SOC) stock also showed significant correlation.

\section{Introduction}

Bamboo as the superb species has been coined with different names across globe like Vietnamese call it 'My Brother', the Chinese 'Friend of the people' and in India it is widely called 'Green Gold' 'Poor Men's Timber' 'Cradle to Coffin timber' etc ${ }^{1}$. About 125 indigenous and 11 exotic species of bamboo belonging to 23 genera are reported in country. Species like Bambusa and Dendrocalamus are found in tropical conditions where as Arundinaria occur in temperate regions. Dendrocalamus strictus is found predominantly in dry deciduous forest while Bambusa bambos flourishes best in moist deciduous forests ${ }^{2}$. Bamboo is an economically important plant and has been introduced in many places in country to protect and restore ecosystems. Bamboo's special biological characteristics and growth habits enable bamboo forests to serve ecological and environmental functions such as land rehabilitation, water conservation and control of soil erosion ${ }^{3}$. Soil microbes also known as 'natural soil engineers' are of different types like bacteria, actinomycetes, fungi, protozoa, nematodes etc are responsible for many biochemical reactions nitrogen fixation, organic matter decomposition, 
humus formation, nitrification, aggregate stabilization etc ${ }^{4}$. Microbial diversity is an important way to gauge soil fertility ${ }^{5}$. Soil organic carbon (SOM) is the amount of carbon content that is stored in soil. Soil organic carbon ( $58 \%$ of soil organic matter) is one of the main factors affecting the storage and supply of nutrients in soil, soil microbial population as microbes use organic carbon as their energy source ${ }^{6-7}$. The soil microorganisms containing about $2-3 \%$ of soil organic carbon (SOC) (6). Soils with high soil organic carbon (SOC) usually have higher microbial biomass ${ }^{8}$. Forest soils have been reported to accumulate considerably higher carbon than other land uses such as savannas and agro-ecosystems ${ }^{9}$.Under bamboo forests, soil enzymatic activities and microbial communities were considerably higher than in the soil from the barren land ${ }^{10}$. Due to rapid growth rate, the species has considerable ability to sequester carbon in soil ${ }^{9}$. So the present study was conducted to investigate dynamics of soil organic carbon (SOC) stock and soil microbial population under different bamboo species in mollisols of Terai area of Uttrakhand.

\section{Materials and Methods}

The present study was undertaken at the experimental site situated at Agroforestry Research Centre, Haldi of G.B. Pant University of Agriculture and Technology, Pantnagar, Distt. Udham Singh Nagar, Uttarakhand. Pantnagar in year 2017-2018 at bamboo plantation established at 2005 . Experiment was done by taking 7 treatments having three replications which include 6 species of bamboo namely Dendrocalamus hamiltonii, Bambusa nutans, Dendrocalamus asper Bambusa bambos Bambusa balcooa Dendrocalamus strictus spaced at $5 \times 5 \mathrm{~m}$ spacing and a control (an open area without any crop). For soil microbial population, the analysis was done up to $20 \mathrm{~cm}$ depth of soil and for soil organic carbon (SOC) stock up to $60 \mathrm{~cm}$ depth. The soil samples were dried under shade, finely processed and sieved through a $0.2 \mathrm{~mm}$ sieve for removing any minute root remains and other minute pieces of litter, debris etc. For counting soil microbial population "Serial dilution plate technique" was used ${ }^{11}$. After colonies development in plates, colonies were counted and their multiplication by respective dilution factor gave number of viable cells per gram soil. Soil Organic Carbon $(\mathrm{SOC})$ Stock $=$ B.D $\times$ O.C $\times$ Depth of soil Where, B.D = bulk density $(\mathrm{g} / \mathrm{cm} 3)$ of soil. O.C = organic carbon content $(\%)$ in soil and expressed in tonnes/hectare. The organic carbon content (\%) of soil determined by modified Walkley and Black (1934) method ${ }^{12}$ as described by Jackson (1967) method $^{13}$.

\section{Results and Discussion}

The result of present study (Table 1 and fig. 1) showed that fungi population was recorded maximum and significantly highest in $D$. nutans $\left(102.10 \times 10^{4} \mathrm{cfu} \mathrm{g}^{-1}\right)$ and minimum was recorded in open plot $\left(53.57 \times 10^{4}\right.$ cfu $\left.\mathrm{g}^{-1}\right)$. The trend of fungi population was followed by the order: B. nutans > D.hamiltonii > D. strictus $>$ B. bambos $>B$. balcooa > D. asper > open. The range of bacteria in soil under different bamboo species was ranged from $35.90 \times 10^{6} \mathrm{cfu} \mathrm{g}^{-1}$ soil to $67.87 \times 10^{6} \mathrm{cfu} \mathrm{g}^{-1}$. D. hamilltonii was recorded maximum and significantly highest bacterial population $\left(67.87 \times 10^{6} \mathrm{cfu} \mathrm{g}^{-1}\right)$ and minimum was recorded in open plot $(35.90 \times$ $\left.10^{6} \mathrm{cfu} \mathrm{g}^{-1}\right)$. The trend of bacterial population was followed by the order: $D$. hamiltonii $>B$. nutans > B. balcooa > D. strictus >B. bambos > D. asper > open. The results showed that range of actinomycetes was varied from $29.45 \times 10^{5} \mathrm{cfu} \mathrm{g}^{-1}$ soil to $53.17 \times$ $10^{5} \mathrm{cfu} \mathrm{g}^{-1}$. The actinomycetes population was recorded maximum and significantly highest in D. hamiltonii $\left(53.17 \times 10^{5} \mathrm{cfu} \mathrm{g}^{-1}\right)$ and 
minimum actinomycetes population was recorded in open plot $\left(29.45 \times 10^{5} \mathrm{cfu} \mathrm{g}^{-1}\right)$

which was significantly lowest than the other bamboo species (Table 2 and Fig. 2).

Table.1 Microbial population under different bamboo species and in open

\begin{tabular}{|c|c|c|c|}
\hline \multirow[t]{2}{*}{ Bamboo Species } & \multicolumn{3}{|c|}{ No of colony g-1 soil } \\
\hline & $\begin{array}{c}\text { Fungi } \\
\left(\times 10^{4} \mathrm{cfu}\right)\end{array}$ & $\begin{array}{l}\text { Actinomycetes } \\
\left(\times 10^{5} \mathrm{cfu}\right)\end{array}$ & $\begin{array}{c}\text { Bacteria } \\
\left(\times 10^{6} \mathrm{cfu}\right)\end{array}$ \\
\hline D. hamiltonii & 101.57 & 53.17 & 67.87 \\
\hline B. nutans & 102.10 & 50.44 & 64.77 \\
\hline D. asper & 82.65 & 37.95 & 52.30 \\
\hline B. bambos & 94.52 & 44.80 & 58.92 \\
\hline B. balcooa & 88.82 & 43.94 & 62.62 \\
\hline D. strictus & 96.90 & 41.61 & 61.72 \\
\hline Open & 53.57 & 29.45 & 35.90 \\
\hline C D at $5 \%$ & 3.024 & 1.053 & 1.922 \\
\hline
\end{tabular}

Table.2 Soil organic carbon stock ( $\mathrm{t} / \mathrm{ha}$ ) under different bamboo species and in open plot

\begin{tabular}{|c|c|c|c|}
\hline \multirow{2}{*}{ Treatment } & \multicolumn{3}{|c|}{ Soil Organic Carbon Stock (t/ha) } \\
\hline & $\mathbf{0 - 3 0} \mathbf{c m}$ & $\mathbf{3 0 - 6 0} \mathbf{~ c m}$ & Mean \\
\hline D. hamiltonii & 50.40 & 36.57 & 43.48 \\
\hline B. nutans & 51.15 & 36.16 & 43.65 \\
\hline D. asper & 47.60 & 30.65 & 39.12 \\
\hline B. bambos & 47.88 & 32.58 & 40.23 \\
\hline B. balcooa & 48.56 & 34.56 & 41.56 \\
\hline D. strictus & 48.64 & 32.38 & 40.51 \\
\hline Open plot & 28.15 & 20.37 & 24.26 \\
\hline C D at 5\% & 1.492 & 0.866 & 1.051 \\
\hline
\end{tabular}

Table.3 Correlation coefficient between microbial population and soil organic carbon (SOC) stock under different bamboo species

\begin{tabular}{|l|c|c|c|c|}
\hline & $\begin{array}{c}\text { Fungi } \\
\text { population }\end{array}$ & $\begin{array}{c}\text { Actinomycetes } \\
\text { population }\end{array}$ & $\begin{array}{c}\text { Bacteria } \\
\text { population }\end{array}$ & $\begin{array}{c}\text { Soil carbon } \\
\text { stock }\end{array}$ \\
\hline Fungi population & 1.00 & $\mathbf{0 . 8 5 0}$ & $\mathbf{0 . 8 5 3}^{*}$ & $0.805^{\text {NS }}$ \\
\hline Actinomycetes population & & 1.000 & $\mathbf{0 . 8 8 6}$ & $\mathbf{0 . 9 3 9}^{* *}$ \\
\hline Bacteria population & & & 1.000 & $\mathbf{0 . 9 0 8}^{*}$ \\
\hline Soil carbon stock & & & & 1.000 \\
\hline
\end{tabular}

* Significant at 5\% probability

$* *$ Significant at $1 \%$ probability 
Fig.1 Microbial population under different bamboo species and in open

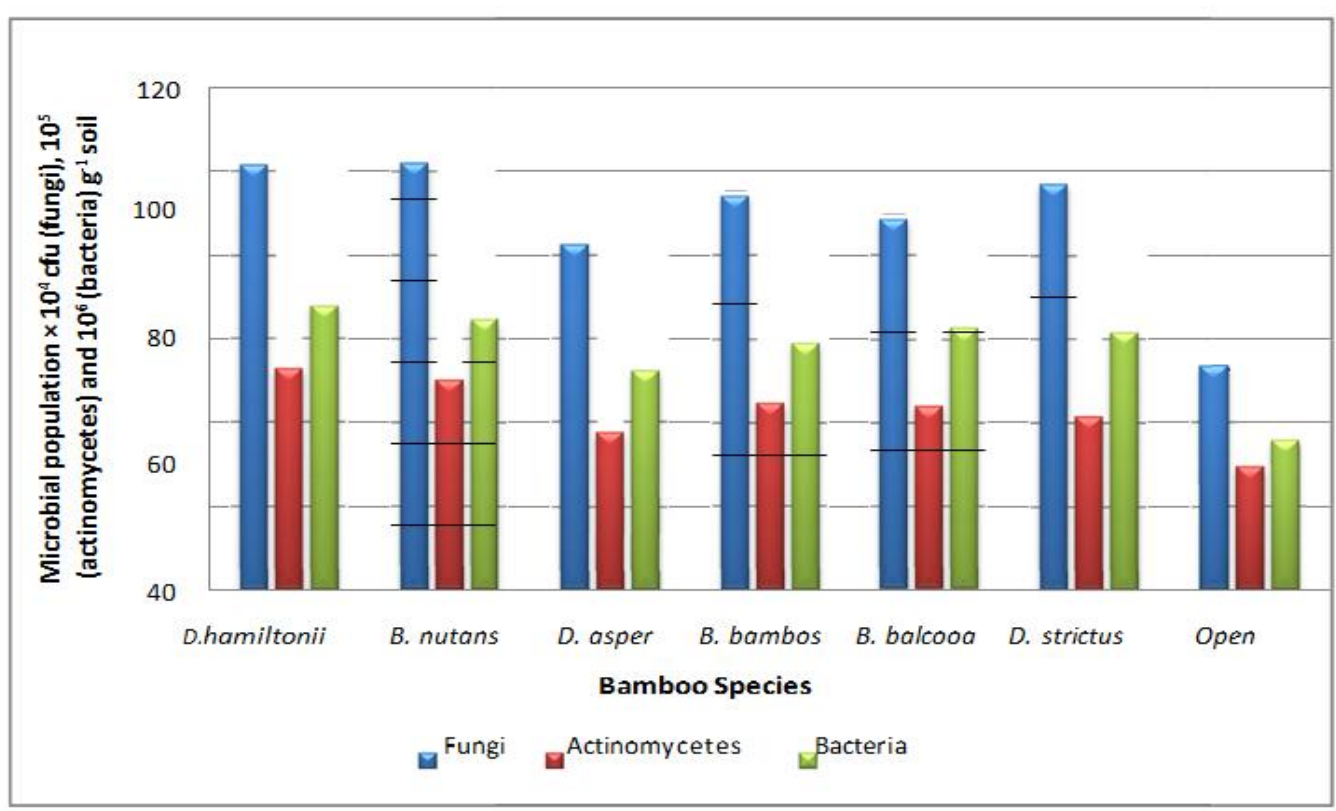

Fig.2 Soil organic carbon stock ( $t /$ ha) under different bamboo species and in open

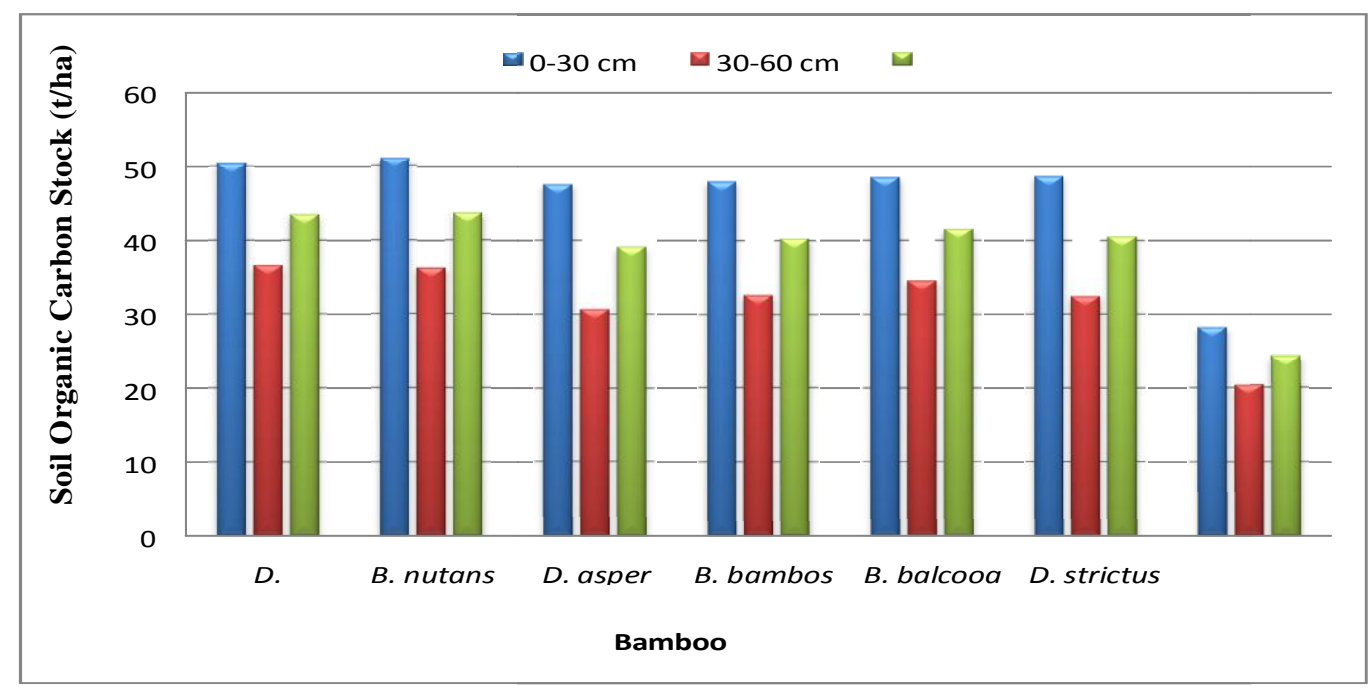

The trend of actinomycetes population was followed by the order: $D$. hamiltonii $>B$. nutans > B. bambos > B. balcooa > D. strictus > D. asper > open. The above findings are in line with Tu et al., (2014) who reported that planting bamboo might help to increase soil microbial and enzyme activities and enrich soil fertility ${ }^{10}$ and Pandey et al., 2012 reported that fungal succession in plantation sites greatly differed from sites without plantation due to the presence of organic materials ${ }^{14}$. The soil organic carbon (SOC) stock was significantly higher under the different bamboo species in comparison to the open plot and also decreased with increase in successive soil depth. The SOC stock for the surface layer $(0-30 \mathrm{~cm})$, maximum $(51.15$ t/ha) was found under $B$. nutans which was significantly highest and minimum (28.15 t/ha) was observed in open plot. For sub- 
surface soil layer $(30-60 \mathrm{~cm})$, maximum (33.57 t/ha) SOC stock was observed under D. hamiltonii and minimum (20.37 t/ha) under open plot. The results supported by similar findings of Richards et al., 2007 reported high SOC stock under the loop pine plantation $(254 \mathrm{t} / \mathrm{ha})$ compared to the pasture land (211 t/ha) ${ }^{15}$. Similarly, Satyawali (2014) also reported highest SOC stock on the surface soil $(0-30 \mathrm{~cm})$ followed by middle layer $(30-60 \mathrm{~cm})$ and lower layer $(60-90 \mathrm{~cm})$ for high density plantations of Eucalyptus hybrid and Melia azedarach ${ }^{16}$. The table 3 and fig. 3 showed soil organic carbon (SOC) stock having significant correlation with all parameters except fungi population. Actinomycetes population and soil organic carbon (SOC) stock reported highest correlation $\left(\mathrm{r}=0.939^{* *}\right)$ coefficient.

\section{References}

1. Zode, R., M. Kawale et al., 2019. Socioeconomic study and traditional uses of bamboo in Gondia (MS), India. February 2019. www. Researchdirections.org.

2. FSI (2017). State forest report. Forest survey India. Ministry of environment and forest.

3. Zhou, G., C. Meng et al., 2011. Review of carbon fixation in bamboo forests in China. Botanical Review. 77:262-270.

4. Sofo, A., P. Fausto et al., 2019. The metabolic and genetic diversity of soil bacterial communities depends on the soil management system and $\mathrm{C} / \mathrm{N}$ dynamics: The case of sustainable and conventional olive groves. Applied Soil Ecology. 137:21-28.

5. Gretston, SJ, 2004. Assessing shifts in microbial community structure across a range of grasslands of differing management intensity using CLPP, PLFA and community DNA techniques. Applied Soil Ecology 25, 63-84.
6. Lal, R., 2014. Social values of soil carbon. Journal of Soil and Water Conservation. 69:186-192.

7. Dai., W. Fu et al., 2018. Spatial pattern of carbon stocks in forest ecosystems of a typical subtropical region of southeastern China. For. Ecol. Manag. 409: 288-297.

8. Babur, E. 2019. Effects of parent material on soil microbial biomass carbon and basal respiration within young afforested areas. Scandinavian Journal of Forest Research. 43(2):94-101.

9. David, C., F. Lalnunmawia et al., 2014.Soil carbon pools of bamboo forests of Mizoram, India. Sci Vis Vol 14 Issue No 1.

10. Tu, Z., L. Chen et al., 2014. Rhizosphere soil enzymatic and microbial activities in bamboo forests in Southeastern China. Soil Science and Plant Nutrition. 60(2):134-144.

11. Chonkar, PK., S. Bhadraray., 2007. Experiments in soil biology and biochemistry. Westville publishing house, New Delhi. 182 p.

12. Walkley, A., IA Black., 1934. An examination of Degtjareff method for determining soil organic natter and a proposed modification of the chromic acid titration method. Soil Science. 37: 29-38.

13. Jackson, ML, 1967. Soil chemical analysis. Prenice Hall Pvt. Ltd. New Delhi, India. p:498.

14. Pandey, AK., V. Ojha et al., 2012. Development and shelf-life evaluation of value added edible products from bamboo shoots. American Journal of Food Technology. 7:363-371.

15. Richards, AE., RC Dalal et al., 2007. Soil carbon turnover and sequestration in native subtropical tree plantations. Soil Ecology and Biochemistry.39: 20782091.

16. Satyali, K. 2014. Studies on biomass 
accumulation, carbon storage and nutrient budgeting in high density Eucalyptus and Melia plantation. M.Sc. Thesis. G.B. Pant University of
Agriculture and Technology, Pantnagar263 145, Uttarakhand. 158p.

\section{How to cite this article:}

Sharma, N., G.K. Dwivedi and Danu, N.S. 2020. Study of Soil Organic Carbon and Microbial Population Dynamics under different Bamboo Species in Mollisols of Terai Region of Uttrakhand, India. Int.J.Curr.Microbiol.App.Sci. 9(10): 227-232. doi: https://doi.org/10.20546/ijcmas.2020.910.029 